\title{
MAKING THE MYTH REAL: THE GENRE OF HEBREW ITINERARIES TO THE HOLY LAND IN THE 12TH-13TH CENTURY
}

\author{
Ayelet Oettinger
}

\begin{abstract}
Medieval itineraries of pilgrimage to the Holy Land conveyed the collective conscience of the society for which they were written rather than the impressions of the individual author. The first Hebrew itineraries were written in the 12th century, probably following the contemporary Christian genre. Yet, despite the evident influence, the Jewish writers succeeded in adopting the Christian genre to the particular needs of their reading audience. This paper explores the characteristics of the Hebrew genre and how they served the purpose of making the myths real.
\end{abstract}

Key words: genre, itineraries (Hebrew), Middle Ages, myth, pilgrimage to the Holy Land, travel literature

\section{INTRODUCTION}

Jewish pilgrimage to the Holy Land was an ongoing phenomenon in the Middle Ages (Friedman 1996). However, for centuries Jewish travelers did not write accounts of their voyage, and Jewish travel literature did not begin until as late as in the 12 th-13th century.

The terms 'travel literature' or 'travelogue' refer to non-fiction journey accounts of distant places, written by, about, or for travelers. This broad and general definition relies only on context. It does not classify the genre regarding form, structure or rhetoric, thus opening travel literature to diverse text types and styles. In his thorough research of 18th-19th-century travelogue literature, Ottmar Ette counts numerous literary forms that can all be included in this hybrid genre (Ette 2003: 26). Jewish travelogue literature in the 12th-13th century was indeed written in the different prevalent literary genres of poetry and elegy, assembly, letter and epistle. Yet, in addition to these genres, all well-known to their readers through other types of subject matter, another form emerged, to which researchers refer, vaguely, as 'travelogue'. Indeed, these are 'logs' - journals of travel - that shall be referred to henceforth as 'itineraries', to distinguish them from general 'travelogue' writing. This 'new' form of itineraries is the subject of this article. 


\section{The Corpus}

The corpus of Hebrew itineraries in the 12th-13th century documents the pilgrimage of six Jewish travelers, see Table 1.

Table 1. The corpus of Hebrew itineraries in the 12th-13th century documents the pilgrimage of six Jewish travelers

\begin{tabular}{l|l|l|l}
\hline & Name (+ henceforward) & Place of origin & $\begin{array}{l}\text { Time of the visit } \\
\text { to Israel (circa) }\end{array}$ \\
\hline 1 & Jacob $(\text { Jacob })^{2}$ & Germany (assumed) & $1153-1187$ \\
\hline 2 & $\begin{array}{l}\text { Benjamin of Tudela } \\
(\text { Benjamin })^{3}\end{array}$ & Spain, Tudela & $1169-1171$ \\
\hline 3 & $\begin{array}{l}\text { Petahyah of Regensburg } \\
(\text { Petahyah })^{4}\end{array}$ & $\begin{array}{l}\text { Germany, } \\
\text { Regensburg }\end{array}$ & $1175-1187$ \\
\hline 4 & $\begin{array}{l}\text { Samuel son of rabbi Samson } \\
(\text { Samuel })^{5}\end{array}$ & France, Provence & 1210 \\
\hline 5 & Jacob (The Emissary) & France & $1258-1270$ \\
\hline 6 & $\begin{array}{l}\text { Disciple of Nahmanides } \\
(\text { Disciple })^{7}\end{array}$ & $?$ & $1270-1291$ \\
\hline
\end{tabular}

${ }^{1}$ Aside from Samuel's itinerary, in which the exact year is stated three times, the other itineraries do not give dates of the travel nor when they were written. This lack of information resulted in different estimations by different researchers. For example, Ya'ari \& Neumark (1946: 81) dates the itinerary of the Disciple as written in the beginning of the 14th century, and in any case after 1290 . But I chose to date the itineraries according to Prawer 1988: 169-250, as it is the most recent and thorough research on Jewish travel literature.

${ }^{2}$ Travels of Ya'akov son of Netanel Cohen, in: Ya'ari \& Neumark 1946: 55-62. English translation in: Adler 1930: 92-100. Henceforth: Jakob.

${ }^{3}$ Adler 1907. This edition contains both Hebrew text and English translation. Henceforth: Benjamin.

${ }^{4}$ Ya'ari \& Neumark 1946: 48-55 (Hebrew). English translation: Benisch 1856. Henceforth: Petahyah.

${ }^{5}$ Ya'ari 1950: 75-83 (Hebrew). English translation: Adler 1930: 103-111. Henceforth: Samuel.

${ }^{6}$ Adler 1930: 115-129. Henceforth: The Emissary.

${ }^{7}$ Ya'ari \& Neumark 1946: 81-98 (Hebrew). There is no English translation. Henceforth: Disciple. 
These works have been widely and deeply discussed by non-literary researchers, who have used the information described in them to broaden our knowledge and understanding of historical, geographical, anthropological, social, cultural and political issues of the Holy Land and world Jewry in that era (for example, see Baron 1952; Dubnov 1968; Friedman 1996; Levanon 1980; Prawer 1988; Reiner 1988; Weber 2004). Literary researchers, on the other hand, have almost totally overlooked this corpus, occasionally dealing with legends imbedded in the texts (for example Hasan-Rokem 1999; Yassif 1999) but not with the collection as a whole. Of course, regarding the collection as a 'whole' requires a perception of it as a 'genre' - a set of stories that share distinctive style, form, and content. These itineraries differ in extensiveness, precision, detail, and literary ability, and might be regarded as the sporadic work of individuals, not bearing any generic qualities. Still, I will try to make a case for considering them a literary genre that disguises itself as reality but in fact blends myths and reality, 'making the myths real'.

\section{Defining a Genre}

The question whether a set of written works constitutes a genre or not, goes beyond the limits of a literary discussion. In the Middle Ages, literary genres derived from everyday needs were defined as reflecting everyday life, and were used for specific, predefined and pre-known purposes. The mere choice of a genre determined for readers and listeners not only the 'how' and 'what', but also the 'why', 'for which purpose'. Genres appeared (or disappeared) by a process that, according to Maja Jakimovska-Tošić, "was connected with the objective necessity of the medieval feudal state and the social estate, the social order, as well as the functions defined for literature to accomplish"(JakimovskaTošić 2003: 1). Hence, understanding the mutual features of a genre can indicate the social need for it. Establishing a 'new' medieval genre assumed that there was a 'new' need. The question, then, is what happened, during the 12th century, to evoke it.

A possible answer relates Jewish itineraries to the prevailing Christian travelogue genre that began at $333 \mathrm{AC}$, and doubled its scope during the Christian regime in the Holy Land (1099-1187). ${ }^{1}$ It is probable that the first Jewish travelogue writers - all from Latin Europe - were acquainted, whether orally or in writing, with Christian itineraries of their time and that their work was directly influenced by them (Prawer 1988: 137, 143). Yet, Christian influence over Jewish literature and culture, during the 12th century, should not be taken lightly: on the contrary, Jews from Europe deliberately abstained from imitat- 
ing common Christian customs - especially if they regarded them as 'devotional' - and thus even refrained during the 12th-13th century from pilgrimage itself, as they came to identify it with Christianity (Reiner 1988: 4). The adoption of a Christian-identified genre despite the general denial of what was connected with Christian piety, may imply that the need for it was so strong that it overpowered both fear and antagonism. Another possibility is that the genre was changed, and thus 'converted to Judaism'.

In what follows, I will survey the corpus of itineraries written by Jewish travelers in the 12th-13th century, with the aim of defining the mutual components by which they can be regarded as a 'genre'(II). The characteristics analyzed include language (1), style (2), narrative structure (3), the image of the traveler as a reliable informant (4), and contextual choices (5). The nature of these components will shed light on the needs that brought about the writing of Hebrew itineraries (and travelogue writing in general) in the 12th century (III) and on the comparisons with the Christian model it imitated (IV).

\section{CHARACTERISTICS OF THE HEBREW TRAVELOGUES}

\section{Language}

\section{The Effect of the Hebrew Language in Terms of Defining the Text}

All itineraries were written in Hebrew, an outstanding feature, given the fact that it was not a spoken language in the Middle Ages. In every place they lived, Jews learned Hebrew for the purpose of prayer, but knew and used the local languages as their everyday tongues, as well as for writing. ${ }^{2}$ Writing in Hebrew was preserved solely for eloquent, formal texts - such as questions and answers in rabbinical discussions (pertaining to Jewish laws and teachings); or for literature - poetry and rhymed prose. The readers of Hebrew were only well-educated Jewish men, usually of the well-to-do classes. Hence, the fact that all itineraries (as well as all travelogue literature) were written in Hebrew, indicates that they were meant for a limited but qualitative target audience, and that their writers considered them either to be pious documents or to have artistic value. 


\section{Style}

\subsection{Scantiness}

All compositions were written in prose, phrased concisely, almost telegraphically, sometimes even inarticulately. The style is barren and the language is very straightforward, using a meager and restricted vocabulary, quite different from the lucidity, eloquence, and allusiveness of the Hebrew language in the genres of poetry and assembly at that time. This short and concise style helps to evoke feelings of confidence and credibility in what was written.

\subsection{Formulaic Pattern}

The things described, or stated, seem like detached modules, strung serially together by a stylistic device of almost monotonous repetitions:

After that a man goes ten parasangs $s^{3}$ to Nob, the city of the Priests, and from Nob to Ludd is four parasangs, and one parasangs to Dudanim, two parasangs to Jabneh, two parasangs to Ashdod and four parasangs to Askelon (Jacob: 92-93).

The connective pattern was achieved through repetitions of words measuring distance such as 'parasangs', 'miles' and 'days' of travel, by stating directions: 'from [---] to [---]', 'thence' and by stating time: and then. The main pattern of forming continuity was through the assiduous use of the 'conjunctive waw' in Hebrew grammar, translated as 'and' (often left out in Adler's translations). The conjunctive 'and' links places, distances, time - and also actions, when attached to verbs, such as the common formula: 'and from there we went to [---] and we saw [---] and we left [---]', et cetera. Thus the writers have succeeded in stylistically conveying an impression of ongoing movement, like the travel itself.

\section{NARRATIVE STRUCTURE}

\section{Linearity - the Structure of the Journey}

The narrative structure of the itineraries emulates the structure of the journey itself. All writers consistently stated the names of the places passed on the route of the pilgrimage, and thus they formed the 'map', which became the basis of the itineraries as well as of the travel. Into this 'map' the writers inserted, dryly, what they considered as important facts. They did not elabo- 
rate, unless they regarded the expansion as a crucial part of the experience. The result seems like lists consisting of names of cities, names of sages, approximate locations and distances, descriptions of tombs and occasionally other things of interest where pertinent. But the lists were 'mixed' together, and the result was a juxtaposing of various, dissimilar facts. The impression is of disorder in the realms of order: on the one hand, the structure of the itineraries is consistent, anticipated and easy to follow: a continuous route, from one place to another. On the other hand, into this route a diversity of information was embedded, in accordance with the incidental things the travelers saw along the way. The linearity is maintained, despite the incidental and disorderly nature of the collected data, because the writers not only placed the information side by side, but also gave it the same significance, as they stated the name of a place they encountered, and a miracle done there, in the same synoptic way.

\section{THE IMAGE OF THE TRAVELER AS A RELIABLE INFORMANT}

The six itineraries belong to two types of travelogue literature, determined by the identity of the writer: (a) the itineraries of Jacob, Benjamin, The Emissary, and probably the Disciple as well, are first-hand accounts written by travelers who have made the pilgrimage themselves. Three were written during the course of the journey, and one - by Jacob - was written retrospectively, after returning to his homeland. (b) The itineraries of Petahyah and Samuel might have been written by them during their journey, but they fall into the category of 'descriptions of a pilgrimage made by others' because they were redacted and edited after the travelers returned to their homeland $s^{4}$ (probably because the works were not considered well-phrased).

Whether written in the first or the third person, the travelers described in the itineraries are fictional entities, not to be recognized as the 'real', biographical travelers. As O. Ette reflected, on the level of the text, the traveler is

[---] a figure modeled by the author, that not least serves as authentication (and later utilization) of the reported, while in this singular division of labor the narrating I undertakes the task of transmission belt that transfers and receives the 'information' (Ette 2003: 30).

The fictional traveler aims to be a 'pure traveler' - who only reports what he has seen himself and ignores every other kind of information (Ette 2003: 30). Indeed, in all the discussed itineraries, the (biographical) writers tried to diminish the image of the (fictional) travelers and their actions, in order to leave 
the stage, so to speak, for the real protagonist of their works - the pilgrimage itself. The described travelers are merely the witnesses-narrators to the events, their informants, and not their heroes. Their own thoughts and deeds are of no interest, unless they serve the real target. Yet, a 'pure traveler' is not conceivable from a hermeneutic point of view (Ette 2003: 30). Hence, at strategic places in the texts, the writers consciously provided the readers with information about the travelers, information that always conveyed meaning beyond personal data itself.

\subsection{Near-absence of Personal Information}

\subsubsection{Scantiness of Actions and Reactions}

Travel literature can be an autobiographical genre. ${ }^{5}$ Itineraries often function as diaries, for they are the written accounts of a traveler's daily activities. Hence it can be expected that they will contain primarily a documentation of the traveler's experiences and impressions, excitement, hopes, fears, difficulties, and exaltation. The first Jewish itinerary writers however, recede into the background, as they write about places and only incidentally about what they did there (Weber 2004: 42). For example, Jacob and the 'Disciple' are practically anonymous, and even Benjamin, who wrote an extensive report, used the first person only four times in his long itinerary (of which three refer to a collective person). ${ }^{6}$

Descriptions of events experienced by the travelers during the journey were also uncommon and often just hinted at. For example, only a few words were devoted to the great difficulties the Jewish pilgrims encountered trying to enter the Tomb of the Patriarchs in Hebron. ${ }^{7}$ Even these rare accounts of personal actions were not incidental, but served a non-personal purpose (4.2).

In the six itineraries, only once - concerning Petahyah - were personal matters brought up for their own sake, ${ }^{8}$ and this was done only outside the borders of Israel. From the Holy Land itself, almost all personal incidents and details were suppressed.

\subsubsection{Lamentation of the Holy Land}

In every exile they endured, medieval Jews lamented Zion degraded of its oldtime glory. It was only natural that this would be done when reaching the Holy Land and physically facing its destruction. In fact, from the beginning of the Byzantine period, Jews came to the Holy Land and to the Holy City almost exclusively to mourn its downcast condition, demolished of its past-splendor 
while under foreign conquest. The rabbis of the Talmud instructed the pilgrims to recite certain verses, perform a mourning ritual for the dead, and pray for the revival of Jerusalem, when visiting it for the first time (Prawer 1988: 133; Friedman 1996; Weber 2004: 37-38). Lamentation was the natural thing to do and to write once in the Holy Land. Indeed a writer of an elegy confessed in his poem that his heart yearned to speak about the virtues of the Holy Land, but could yield only tears and a tale of woe. ${ }^{9}$

Strangely enough, in the itineraries there were no expressions of feelings and actions regarding the Holy Land. The writers did not report of joy when reaching it, or typical customs such as kissing the land, praying, blowing the horn of a ram and thanksgiving. Neither did they tell of the grief, weeping and mourning over the Holy Land. Only regarding Jerusalem, Samuel reported at length:

We arrived at Jerusalem by the western end of the city, rending our garments on beholding it, as it has been ordained we should do. It was a moment of tenderest emotion, and we wept bitterly, [Rabbi Jonathan] the great priest of Lunel and I. We entered by the [western] gate [---] as far as the Tower of David, whence it is customary to proceed for prostration before the approach to the temple. We fell on our faces before the Shechem Gate [---]. From there we went to Mount Olivet, where in olden times the red heifer was burnt. We said our prayers there twice with a minyan ${ }^{10}$ and climbed the mountain. On the Sabbath day we recited the Afternoon Prayer [---] (Samuel: 103-104).

These are the words opening Samuel's itinerary, and they are exceptional. Aside from them, only the Disciple gave account of the mourning ritual:

When we reach Zophim, we see Jerusalem and make one rent in our garments, and when we reach Jerusalem we go on one of the ruins and look at the Temple Mount and the wall of the Court of Women, and the Court of Israel, the site of the Altar, and the site of the Temple, and the Sanctuary, and we make a second rent in our garments for the Temple (Disciple: 85). ${ }^{11}$

Unlike Samuel's stirring and detailed depiction, the Disciple's report was told in a dry and concise manner, as if telling of a custom, not relating an experience. Even Benjamin, who elaborated on Jerusalem and mentioned the crusader rule in it, remained loyal to an objective description and did not express his emotions. The scantiness of expressed emotions regarding the degraded situation on the Holy Land, is surprising especially considering the magnitude of its manifestation in liturgical poetry, as well as in travelogue literature in 
verse, rhymed prose, letters and epistles. ${ }^{12}$ Descriptions of religious ritual also constitute an important part of Christian travel literature (Wilken 1996: 123). Hence, it seems unlikely that this absence of important, religious data, having to do with the essence of pilgrimage, is incidental. Rather, it can be assumed that this is a conscious characteristic of the genre. Knowing that, in the Middle Ages, different genres served to express different purposes, the question is what purpose this intentional abstinence came to serve, a question that will be considered henceforth, in the discussion (III).

\subsection{Personal Information for Validity}

The genre of itineraries depends on the readers' trust that it indeed depicts objective reality and nothing else. The confidence of the readers in the credibility of the text is achieved through creating confidence in the character of the traveler. The figure of the traveler is made to appear as a trustworthy man, by four characteristics, as follows.

\subsubsection{Empiricism - the Travelers as Eyewitnesses}

In all itineraries, except for Benjamin's, the writers occasionally remarked that the travelers mainly 'went', but also 'saw', 'walked', 'came', 'found', 'journeyed' et cetera. In Samuel's itinerary this was done frequently, and Jacob explicitly emphasized: I write of what I saw with my own eyes (Jacob: 99).

The stating of actions authenticates the itineraries as reports of what the travelers actually saw and did. But 'seeing' and 'walking' in the Holy Land, reveal more than just 'seeing' and 'walking': they also stand as metaphors for 'participation' (Wilken 1996: 132) and as 'testimony for the supernatural and sacred' (Campbell 1988: 39). Jewish itineraries are more restricted than the Christian itineraries; they do not stress the travelers' actions as often. In fact, in Benjamin's itinerary the character of the writer-traveler was completely omitted. Everything was written as an account of objective facts, which seemingly had nothing to do with his character. Still, even a few verbs have a cumulative effect, and they add up to construct the veracity of the travelers as people who have actually 'been there' and therefore give firsthand (presumably also 'reliable') information.

\subsubsection{Ancestry}

Names are more than 'copyright' - the identity of a writer-traveler who wanted to be recognized and remembered. The mere mentioning of names gave the 
texts validity by showing that their authors did not hide, but exposed themselves true to their words. Kinship bestowed on the traveler the same as in the old adage "tell me who your friends are, and I'll know who you are". Maybe this is the reason why in all six itineraries the readers were informed of the travelers' relations or familiarity: Jacob began his itinerary with the acknowledgement I, Jacob, the son of R. Nathaniel haCohen (Jacob: 92); the scribe of Benjamin's itinerary stated in the heading that Benjamin was the son of Jonah, of the land of Navarre (Benjamin: 2); and the editor of Petahyah's itinerary ended it with the words: End of the words of Rabbi Petachia, brother of Rabbi Yizehak, the White, author of the Tosephoth, and of Rabbi Nachman, of Ratisbon (Petahyah: 67). The writer of Samuel's itinerary related that Samuel was in the Holy Land with Rabbi R. Jonathan haCohen, of Lunel (Samuel: 103), and the scribe of The Emissary elaborated that Jacob was the truthful messenger of R. Yehiel of Paris, who has in his Yeshiva 300 students, may God protect them (translation by Prawer 1988: 231). The 'Disciple' did not mention his own name, but he did identify himself by his master, Moses son of Nahman of Gerona (Nahmanides). In the last four works, the travelers were related as brothers, companions, and followers of important and well-known Jewish religious leaders, teachers, and scholars. The latter's piety served the writers in bestowing piety on the first, another important factor in creating credibility (as follows).

\subsubsection{Wisdom and Religiousness}

As the usage of Hebrew indicated, itineraries were written for an audience of religious, educated men, and perhaps were regarded as religious writing, describing 'religious travels'. Accordingly, the writers built the authority of the traveler by pointing to devoutness (Weber 2004: 43). In the case of Benjamin, this was done explicitly, describing him in the heading of his itinerary, as a wise and understanding man, learned in the Law and the Halacha ${ }^{\mathbf{1 3}}$ (Benjamin: 2). In the other itineraries, the virtue of religiousness was attached to the travelers through indirect characterization.

Beginnings and endings are strategic points, where an exclamation of thanking the Lord or asking for his blessing, immediately marks the traveler as a pious man, attributing all of his work (or travel) to God. Thus the opening lines of Jacob's travel, are I, Jacob, the son of R. Nathaniel haCohen, journeyed with much difficulty, but God helped me to enter the Holy Land (Jacob: 92), and the Disciple opens for your salvation, God, I hoped for (Disciple: 83). The closing line of Benjamin's itinerary is May God, the Blessed One, have mercy upon us and upon them! (Benjamin: 81); of The Emissary: May the Lord support us and may we live in His presence. May He give us merit to see them alive speedily in 
our days! (The Emissary: 129). The Disciple ends with an extensive epilogue full of the Holy Land's panegyric, its particular relation with God and the Jews, and messianic inspiration (Disciple: 97-98, Prawer 1988: 244-245).

The devotional identity of the informants is evident also from their behavior and words throughout the works. For example, Samuel opened his itinerary by depicting prayer and lament over Jerusalem (Samuel: 103-104), Petahyah taught prayers to Karaite heretics (Petahyah: 7, 9), Jacob and The Emissary quoted verses from the Bible as proof for outstanding phenomena in Israel (Jacob: 99; The Emissary: 120), and the Disciple revealed a sense of personal pride whenever he succeeded in identifying an exact location according to Biblical and rabbinic sources (Disciple: 85, 92, 93). All travelers show proficiency in the religious sources, naming places in Israel not only by their contemporary but also by their Biblical and Talmudic names, and example is plentiful. An interesting literary use of the traveler's figure and mentioning of his name, as a method of opposing intimidating Christian identity, was demonstrated by Weber (2004: 42-44).

\subsubsection{Thoroughness and Trustworthiness}

The reliability of Benjamin is stated clearly in the headings of his itinerary: The anonymous relater of his travels, declares wherever we have tested his statements, we have found them accurate, true to fact and consistent; for he is a trustworthy man, attesting also to his informants: In every place which he entered he made a record of all that he saw or was told of by trustworthy persons (Benjamin: 2). The Emissary is named, at the heading, the truthful messenger (Prawer 1988: 231), and Samuel's itinerary ends with the statement I have a firman with the seal of the King of Jerusalem attesting the truth of the present writing (Samuel: 110).

The reliability of the travelers depends not only on what they 'saw' but also on what they heard. As strangers in the land, they had to rely on local informants (perhaps even professional 'travel guides') for learned explanations, such as how they succeeded in carving the burial caves in a stony mountain (Jacob: 94), why the water holes on the Mount of Olives were not full (Jacob: 99), or what the source of the huge rocks used to build the wall of Ezra in Jerusalem was (Disciple: 86). They relied on their intelligence - such as, to identify upon which exact oak Abraham's angels leaned and on which precise stone Abraham circumcised himself (Petahyah: 67), and told stories of miracles in the names of the people from whom they had heard them. ${ }^{14}$ The mere mentioning of their inquiries added to their reliability, as it proved that the travelers had made an effort to achieve authentication, comprehension and precision. Moreover, if 
they were unsatisfied with their inquiries, they said so, and pronounced their difficulty, reservations and even explicit disbelief in the information handed to them (Petahyah: 61, 63; Disciple: 87).

\subsection{Conclusion}

Whether the real, biographical travelers were the writers of their itineraries or they only related their tales to others, their image in the realms of the literary work was fictional and thoughtfully calculated. The travelers' image was not of a protagonist, but of an informant providing information about the pilgrimage in the Holy Land. As such, personal data about the traveler was of no importance, unless it served to persuade readers of his credibility - a thing crucial for believing his information. Hence the travelers were portrayed as family people related to rabbis. Their only characteristics mentioned were their being pious, learned, curious, and dubious - all traits that portrayed them as able to investigate and estimate what they encountered on the basis of reasoning and knowledge. This clear specific choice kept the itinerary genre from being a personal 'diary', and instead displayed it as a 'public' genre, in which the traveler (writer) speaks for the whole community, just like in religious poems and prayers. On this basis, it is odd that the travelers did not express their feelings of joy at reaching the Holy Land, or sorrow at its destruction.

\section{CONTEXTUAL CHOICES - BLINDNESS AND VISION}

The same focused yet narrow scope that was used to qualify the image of the traveler as a credible source of information was also used in selecting the content. In the Holy Land, the travelers saw only the 'Holiness': places, Tombs of sages, and legends of their miraculous powers, were broadly portrayed, while people and things of interest were overlooked, unless their depiction added to the depiction of the pilgrimage.

\subsection{Places}

Travel literature is defined as a type of literary and scholarly writing, in which writing becomes perhaps the most conscious about its reference to space, its dynamics and its needs to move (Ette 2003: 17). In the Hebrew itineraries, all writers meticulously mentioned all the places they visited, thus forming the 
structural skeleton of their works. Concerning the places, there are four observations:

\subsubsection{Sequence of Sacred Space}

The list of places forms a linear continuity of travels all over the Holy Land, as if the travelers recorded the chronological and geographical sequences of their journey. Whereas Christian travelogue writers described only places of holy interest, following 'the footsteps of Jesus' (for example, see Eliade 1957: 1339 ), each of the Jewish writers depicted a different route with different stops on his way, as if the whole of Israel was considered 'sacred space', and therefore the emphasis was on roaming it, and all places were equal, aside from the obvious religious locations - Jerusalem, Hebron and places in the Galilee where numerous sages were buried.

\subsubsection{Quantity}

The travelers listed many places they had apparently visited, ${ }^{15}$ yet the repetitions, inconsistencies, and discrepancies in distances, measurements, and locations, between the travelogues and reality make it difficult to believe that these were faithful depictions of the travel. ${ }^{16}$ In fact, the travelers were not necessarily in all the places mentioned in their itineraries, but relied on readymade 'regional lists' of holy places, which they imbedded to supplement their texts. ${ }^{17}$ This shows that their main intention was not to document their own realistic track, but rather to give a full list of the holy places in the Holy Land, displayed as a part of a continuous journey. The motive might have been political-national, as naming an abundance of places, all over the land, can testify to a wish of showing ancient Jewish ownership over it.

\subsubsection{Naming and affinity to the past}

Most of the time the writers made do with mentioning just the epithets of the places in the Bible and in Rabbinic Literature. The mere act of signalizing the Biblical-Rabbinical epithet of a place immediately charges it with a dimension of awe and sanctity, an act that is consistent with a religious motive. If the writers elaborated on a place, it was usually concerned its with far-past traditions, such as who and what were there in biblical and Talmudic times, ignoring any attractions at the time they visited the places. In so doing, it seems that the travelers consciously chose to prefer the glorious past and to refuse recognition of the new rulers of the land and its destruction in the present. 
This selective choice meant a denial of the present. In the travelogues, the land of Israel belonged to Jews alone.

\subsubsection{Realistic dimension}

Places and landscapes of Israel were also remembered in contemporary Andalusian Hebrew verse. Although the Spanish poets did not exceed the realms of 'literary' or 'holy' geography, as they relied solely on the Holy Scriptures for their descriptions, the writers of the travelogues stressed distances, days of travel, and verbs in the first past tense, emphasizing that they physically walked the Holy Land. The emphasis put on this realistic dimension creates an affinity between the biblical, religious past and the realistic present. With their bodies, the travelers united past and present and enabled their readers to become a part of their pilgrimage in the present and at the same time to touch - through them - the sacred past. In addition, it strengthened the affinity between the readers and the land, turning it from an almost fictional-utopian and remote, divine place, known to them exclusively from prayer, into a realistic, concrete, almost tangible one.

\subsection{Tombs and relics}

The pilgrimage of the travelers in the discussed itineraries focused on the graves of sages and famous men - mostly Talmudic but also biblical, and in one case even coeval (Disciple: 83 ). In addition the travelers described relics - such as the well of Miriam that was immersed in the lake of Kinnereth yet reveals itself as a wheel rising high out of the water everyday at noon, ${ }^{18}$ an angel's footprint (Petahyah: 57), as well as more concrete remnants, like the altar that Elijah repaired in the days of Ahab (Benjamin: 19), or the pool used by the priests before offering their sacrifices in the temple (Benjamin: 23). Presumably, the travelers chose routes intended to bring them to these places and graves that they heard of and wanted to see, meaning that the places mentioned in section (4) were secondary to the 'tombstone tour' - the reason for which the travelers reached those places in the first place. Two characteristics are as follows:

\subsubsection{Identification and validation}

All travelers were primarily occupied with listing the tombs and relics they saw. They strove to identify who was buried where, but even reported anonymous graves. Identification was indeed a problem, especially when the pil- 
grims described relics like the 'exact oak' Abraham's angels leaned upon, and the precise stone on which Abraham circumcised himself (Petahyah: 67). Because of the ambiguous nature of such relics, the travelers needed methods of confirming the truth, and stressed that they relied on local sources to determine the identity (Petahyah 4.2.4). ${ }^{19}$

\subsubsection{Description}

The travelers stated the location and landscape of the tombs, tried to explain the different methods of burial, supplied their readers with grave measurements, specific building materials (marble, hewn stone, or huge rocks) and architectonical shape (form, cupola, dome, columns, or number of rocks on it). They specified captions, inscriptions and ornaments found, outstanding accessories (such as basins or iron pieces), the entrance to the site (if it included stairs, special turns, tunnels), the need for bribes in order to gain access, specific rituals done in the sites (such as writing or carving names upon walls and pillars ${ }^{20}$ or placing stone receptacles of bones of dead family members inside).$^{21}$ Some of them even expressed their opinion on aesthetic matters - if a grave was 'comely' or even 'very beautiful'. The detailed description protrudes especially when compared with the overall diminution of account in the itineraries. It emphasizes that attending the graves was the summit of the pilgrimage, and the realistic elaboration was what enabled the readers to take part in it.

\subsection{Stories of Miraculous Powers}

Legends describing the miraculous powers of the deceased were embedded in all travelogues. They were well anchored in definite times and places, concentrated around the images of the holy men buried in the tombs, and aimed faithfully to display what the writers regarded as historical reality, told directly as true traditions - 'memories' - that they had heard from 'credible people' or seen 'with their own eyes'.

These miraculous folktales were probably widespread orally among Israeli populace, reflecting the collective conscience of the Jewish society at the time. In them, the dead were not dead but very much alive, and active in the present. The deceased sages are portrayed as having divine power to overpower nature. With their ability, they not only guarded their own tombs, but also benefited their believers, and harmed those who despised them. This gave hope and symbolized their ability to guard the Holy Land as a whole (Prawer 1988: 174; Weber 2004: 38-39). It seems that the legends enabled their audience, 
passionately desiring to believe in miracles (Sumption 1975: 65), to deal with the difficult reality in Israel in those days.

\subsubsection{Overpowering Nature}

Legends depicting the ability to overpower nature were used as an etiological device for explaining peculiar phenomena. For example, heavenly intervention was ascribed to the placement of huge rocks or heavy pieces of metal, too heavy for men to lift, on the tops of some graves (Petahyah: 59, 61). Where Martyrs were executed, no grass shall ever grow (Jacob: 97). When one stone falls off a grave, the whole tomb is immediately surrounded by a branch of a supernaturally growing tree, thus preserving it against the ravages of time (Samuel: 109). Out of tombs comes a good scent that spreads up to a mile away (Petahyah: 55).

\subsubsection{Goodness}

The supernatural power of the graves was made apparent in the abundance of goodness they could create: men could take soil to build houses from Adam's grave, yet it does not grow less, and is full at any time (Jacob: 97). Sheep continually lick the Pillar of Salt into which Lot's wife was turned; but afterwards it regains its original shape (Benjamin: 23). Springs of water flow from the graves (Petahyah: 57), yet though one should draw from the stone a thousand jugs of water, it would not be diminished, but would remain full as before (Petahyah: 57). The water flowing from tombs is always 'sweeter than honey' (Jacob: 96; Petahyah: 67; Samuel: 108) and fruit growing on nearby trees is always ripe (Samuel: 108). The sick and barren come to R. Cahana's tomb, and are healed (Jacob: 95).

Yet, only believers can enjoy these things: when men of worth enter the catacomb of Hillel and Shamai, the stone appears full of sweet water. [---]. To an unworthy man the water does not appear (Petahyah: 57). Many times the sinks in this place were dry, yet become filled with water in an instant during prayer (Disciple: 90). The holy places keep the Jewish law: a spring flows all six days, but on Sabbath not a single drop is found in it (Peta hyah: 57). Placing pieces of the stone on which Abraham circumcised himself, over circumcision wounds, helps them recover (Disciple: 88 ). The things that the holy places gave their believers were symbolic: eternal nourishment (plentitude of sweet fruit and water), land (never lasting soil and salt), and health. 


\subsubsection{Self-protection}

Holy sites supernaturally preserved themselves: tombs are totally covered with myrtle or trees, so that no man can touch them (Disciple: 92; Samuel: 106), they are guarded by lions and serpents (Jacob: 97 ; Disciple: 87 ), as well as by earthquakes (Petahyah: 65) and storms (Jacob: 98; Benjamin: 24-25). No oneJews and Gentiles alike - is allowed to take even a leaf from their surrounding vegetation (Disciple: 92; Samuel: 106, 109). It is possible that the elaboration of the travelers on the exterior look of the tombs had to do not only with identification, but also with wonder at the fact that they are intact, in the crumbled land, ascribing this, too, to miracles.

\subsubsection{Punishment}

Most of the legends demonstrate how the graves protect themselves from irreverent non-Jews, exhibiting disesteem or wishing to damage them. Priests who wish to make changes in holy sites - take a stone from a grave to fix in their church for strange service (Petahyah: 59), close a wicket (Jacob: 98) or open a closed gate (Petahyah: 65) - repeatedly fail to do it. Icons built over holy graves keep on falling (Samuel: 104; Petahyah: 89). Whoever tries to plunder the graves, to despise them deliberately or even just to take wood from the surrounding forest - is either frightened for his life, or dies (Benjamin: 24-25; Petahyah: 65; Jacob: 96, 97, 98).

\subsection{Curiositas'}

The description of interesting things that were seen by the traveler in the course of his voyage is an eminent feature of travel literature. It conveys the traveler's interest in what he sees and the reader's in what he hears and the fascination of such matters for the curious reader was not lost on the author (Howard 1980: 23). The writers of the itineraries were probably also aware of this, yet inside the Holy Land, the fascination was reserved only for sights, places and tombs bearing religious and national meaning, as explained above. Interest in Curiositas' was exhibited only outside the borders of Israel: Except for Samuel, whose work was redacted by an editor that omitted all reference to places outside of Israel (Reiner 1988: 40-41), the writers described in their travelogues the route that brought them to the Holy Land or that they took from it. The description of the voyage reveals a keen interest in the exotic and exceptional: While depicting these parts of the voyage, the travelers gave detailed accounts not only of encounters and conversations they had with the 
local populations, but also of outstanding architecture, art (sculptures, bronzecarving and marble engraving), useful inventions (lighthouse), landscapes, exotic animals (elephant, a flying camel) unique vegetation (mandrakes), and much more.

It is important to stress that the Holy Land did not lack things of interest. It was the choice of the writer to prefer Pilgrimage to Tourism. In this aspect, as well, the difference in the things transmitted to the readers reveals a different attitude towards Israel than other countries.

\subsection{Characters}

The travelers relied on local hospitality, met many people and were probably curious concerning different customs, opinions, politics, et cetera. Yet, all this found expression only regarding communities outside the Holy Land. ${ }^{22}$ From within the realms of Israel, there were so few references to Jews, non-Jews and the foreign regime, that Joshua Prawer concluded that the itineraries are written in a kind of spatial and historical vacuum (Prawer 1988: 175). This is another testimony to the writers' conscious suppression of all details they considered irrelevant and subordinate. Natives interested the writers, only regarding two features, as follows:

\subsubsection{Jewish communities and individuals - scantiness of informa- tion}

Benjamin made note of the population of Jewish communities everywhere he went, including in the Holy Land, even if the remark is There are no Jews here (e.g., 20). The population is mentioned also by Petahyah (55), and Samuel (109); but all this is scarce and written dryly, as a documental report. Personal names or features were stated only by Benjamin and Petahyah, and in two cases: (a) esteemed Jewish people - leaders, scholars and sages - were specified systematically by Benjamin, and occasionally by Petahyah (although in Israel only once, Petahyah: 55). This may testify to a wish of showing that there was worthy leadership all over the Jewish communities. In addition it can be interpreted as a panegyric obligation, a way of thanking men that gave the travelers hospitality. ${ }^{23}$ (b) Benjamin and Petahyah elaborated on people that gave them first-hand testimonies of miracles. In these cases, the elaboration was needed to portray the informants of the miraculous stories as trustworthy (ibid 4.2.4). Aside from these, the travelers referred to characters mainly collectively, as 'the local people', 'Jews' (or more specifically: 'the Jews of Acre'), 'Rabbis', as well as 'Gentiles', 'Ishmaelites' (for 'Muslims'), 'Priests and cardinals', 'all na- 
tions'. All information regarding them was indirect and incidental. For example, from the words and I, Jacob, said to the Rabbis - it is clear that there were Rabbinic Jews in Jerusalem (Jacob: 99). Kindness and benevolence of locals were mentioned only by way of relating difficulties in entering the Tomb of the Patriarchs in Hebron, or the honor bestowed upon the Jewish great leader that traveled with Samuel's group (Samuel: 105; 109).

\subsubsection{Validation of the Jewish Belief}

The writers of the itineraries showed interest in locals mainly for indirect characterization of the tombs. They incorporated many details of the tomb rituals among the natives, including how Muslims worshiped Jewish holy men, made vows at their graves, left offerings there, lighted candles, and prayed (Jacob: 95, 96; Benjamin: 23; Peta hyah: 25, 27, 35, 39; Disciple: 84, 85, 86, 90; Samuel: 104, 107, 109; The Emissary 116, 118-119, 125-126). The Disciple even depicted what seems like a joint Jewish-Muslim festive-prayer for a blessed, rainy year (Disciple: 90 ). Non-Jewish keepers of the holy places allowed only Jews in the real Tomb of the Patriarchs in Hebron (Benjamin: 25; Petalyah: 54,59 ), or gave only Jews fruit of Jonah's garden (Petahyah: 63). Even the fact that mosques and churches were built over sites that were holy for the Jews (Benjamin: 19, 23, 25, 26; Jacob: 98; Disciple: 86, 92; Samuel: 104) is mentioned as it attests to Gentiles admission of the power of Jewish sages and holy places. Correspondingly, the writers described Gentile disrespect for Jews and desecration of graves: some custodians lied to Jewish travelers, making it difficult for them to enter some of the tombs (Benjamin: 25; Jacob: 98; Disciple: 91), tomb-stones were used for building (Benjamin: 24), dead were taken out of their vaults seeking the golden thread with which their cerement was sewn (Jacob: 59), and some graves were violated (Jacob: 59; 60). All these incidents also are not described for their own sake - to show the miserable condition of Jews in their promised land - but to emphasize the power of the deceased sages to harm those that disrespect them, thus reinforcing the Jewish belief (Weber 2004: 46).

\subsection{Conclusion}

The Hebrew itineraries of the Holy Land were entirely concentrated on the pilgrimage. They portrayed a wide and continuous sequence of places, all known from the Jewish nations' past, and hence all holy and worth mentioning. They focused solely on tombs of sages, going from one to the other, naming the deceased, depicting the graves, and relating legends of miracles performed by 
their occupants. In contrast to the quantity of dead sages' and holy men's names that were mentioned, stands the scantiness of names of the living. The writers almost ignored the people inhabiting the land and seldom described things of interest, unless it served to support the main issue of tomb-traveling. Only in other places on their voyage did the travelers allow themselves to be 'tourists', describing and even elaborating on the foreign, extrinsic, and wondrous, for their own sake.

Reading the itineraries, one gets the impression that it was the dead - not the living - that inhabited the land. The tombs of the deceased were a real, tangible entity that became the 'hero' of the itineraries. They did not just hold form and structure, but were active, vital, and had a current existence of their own. The dead sages and holy men were the real landlords - the keepers of the land. Even Gentiles believed in them, and whoever tried to disdain them, or even to touch them, was severely punished. Furthermore, the dead took care of their believers, supplying them with protection, nourishment, and health. They were active not only in the past - but also in the present. And if the dead - scattered all over Israel - were active, strong and 'alive', in the eyes of the believers, it meant that the Holy Land was not forsaken. Moreover, it meant that salvation would come, maybe even that it was near.

\section{DISCUSSION}

From their first appearance in the 12th-13th century, Hebrew itineraries were a literary genre with specific characteristics. In the Middle Ages, each genre had a designated audience, and an assigned purpose. The genre of itineraries was very popular, as can be deduced from the multiple copies of itineraries that survived. The questions are: what was the incentive for writing them, and why were they so popular?

Despite the fact that itineraries have a diary-like and a biographical aspect, the Jewish itineraries were not personal literature. They did not preserve the travelers' voyage for they did not document personal adventures, events and encounters, nor did they consist of private memories and feelings. In fact, even the most prominent feature of the Hebrew itineraries, the track of the pilgrimage itself, was not necessarily real, but rather supplemented with names from 'regional lists' of holy places in Israel. The first Hebrew itineraries were not a private-documental genre also because, written in Hebrew, they were addressed to a specific crowd of Jewish educated men. They were written in a very formal, concise prose, with an impersonal, objective tone, descriptive and factual rather than narrative and fictive. The choice to summarize was a sty- 
listic choice. The contraction indicated a wish to be precise, as if the compositions aimed to be scientific rather than literary. The precision conveyed credibility, assuring the readers that only reality was described. It seems as if the writers strove to present their works as credible, realistic, and objective, depicting the narrators as dependable informers, giving exact distances and names and sifting out the rest. The itineraries were written for others to read and to believe.

Because itineraries did not include exotic or interesting details regarding the Holy Land, they could not have been written for the purpose of satisfying curiosity. They did not provide pilgrims-to-be with practical knowledge, and the information in them was banal, not portraying the land - its flora, fauna, geography or architecture. In fact, they did not supply Jews in the European exile with more than a list of names of places and sages that they had already known from the Holy Scriptures. Yet, the itineraries were not designed for the aim of spiritual exaltation either. They did not express pious emotions, prayers or rituals. On the contrary, they were surprisingly restrained and self-controlled regarding the Holy Land. Unlike other Hebrew genres of travel literature, the writers of the itineraries did not express joy at finally reaching the long pined-for land of their fathers, nor did they lament at seeing its devastated, ruined condition, under foreign religions at the travelers' present. The documental, factual information they conveyed did not stimulate devotional sentiments. They came to evoke something else.

The writers of itineraries disguised their works as objective literature depicting reality. The truth is that they disclosed the exact opposite. The reality described in them is selective, subjective, and limited, conveying only myths that the writers desired to be seen and read. The writers ignored the fact that the Holy Land was occupied by 'foreigners' and focused on roaming it freely and on the power of deceased sages to act. This reveals a wish for salvation, pronounced openly by the writers. Written for people who lived in exile and suffered from humiliating laws, violence, destruction and massacre that were the lot of Jews in the anguished Diaspora at that time, the itineraries were aimed at supplying their readers with national and religious consolation. The illusion of reality was important, for it transmitted credibility that was crucial for conveying their religious-national message. Only if the readers believed that the itineraries reflected the true situation in the land - a situation in which the magnificent past was recognized at every place, the painful present was overlooked, and the dead were alive - would they be comforted by it.

This brings an interpretation of the itineraries with the eschatological circle, so fundamental in the writing of Jewish poets in the Middle Ages: The eschatological circle starts in the present, looks back at the magnificent past - 
before the Diaspora of the Jewish people - and expresses the wish to renew the past - to return to Israel in a majestic future. The itineraries did not lament the destruction, they suggested the revival. The faith in the power of the tombs implied a passion to reconstruct the present. The writers acted out of a determination to strengthen their readers, to provide them with hope and defense - even if only psychologically - against their persecutors and difficult times. This - even if not said directly, but merely hinted at through folktales.

\section{HEBREW ITINERARIES AND CHRISTIAN TRAVEL LITERATURE}

As said above, the first Hebrew itinerary writers were probably acquainted with the Christian genre that preceded them. The influence is discernible in the stenographic style, in the documentation of holy places, including directions and distances, and in avoidance from documenting much else. Christian itineraries also reported myth and reality alike, interfused miraculous stories with objective data, concentrated on the holy pilgrimage and not on tourist sightseeing. Yet, despite the similarities, there are contrasts as well. To begin with, the personal voice of the Jewish pilgrim-traveler was rarely heard, whereas the Christian pilgrim disclosed his feelings and excitement, exhibited devotional rousing, and lengthily described religious ritual. Other differences are that whereas the summit of the Jewish pilgrimage was 'tombstone tours', mainly to graves of Rabbinic sages, from the near past, Christian pilgrims described only few tombs and clung to places related to Jesus and to stories from the Holy Scriptures. As a result, the holy geography was different, because for Jewish pilgrims all the land was holy, whereas Christian travelers sought only places related to their religious past. Contrast is evident in the aspect of 'sacred time' as well, for the Christian itinerary writers looked for the ancient Holy Land, the place where things happened in illo tempore, whereas Jewish writers sought a mythical present - dominated by the working powers of deceased sages and holy men.

Both Christian and Jewish itineraries were genres of recruited literature, aiming to convey the collective conscience of their societies at the time. Yet, whereas Christian general cognition was religious, aiming to stir up devotional sentiments from the Holy Land to believers in their homelands, Jewish general cognition was national, seeking to convey consolation and hope for suffering people, far from their home land, in exile. It is obvious, then, that the Christian genre was not taken 'as is', but rather changed to suit the different, Jewish purposes of its writers and their readers. Maybe this different purpose 
is what enabled the story of Jewish pilgrimage to the Holy Land to be written following a Christian genre, at a time when pilgrimage itself had almost stopped, for fear it may be interpreted as following a Christian custom.

\section{COMMENTS}

1 On Christian travelogues of pilgrimage to the Holy Land immense research was written (see, for example, Baron 1952; Howard 1980; Kollek 1970; Le Beau \& Mor 1995; Reiner 2003; Sumption 1975; Wilken 1996; Wilkinson 1977; 1999; Wilkinson \& Hill \& Ryan 1988).

2 The dimensions of using the vernaculars as opposed to the usage of Hebrew, can be realized from the vast majority of manuscripts written in Judeo-Arabic concerning all realms of life, found in the Cairo Geniza (see also Goitein 1967-1993).

3 Persian miles (about $4.5 \mathrm{~km}$ each).

4 Petahyah's travelogue was redacted at least twice, maybe even three times according to Prawer 1988: 206-207.

5 The parallel between autobiography and travelogue has often been acknowledged, see Ette 2003: 30 and the reference there.

${ }^{6}$ I journeyed first from my native town to the city of Saragossa [---] from there I went [---] (Benjamin: 2, the opening words of the book); For the men of Babylon are accustomed to read a portion every week, as is done in Spain, and is our custom (Benjamin: 70); when the Lord will remember us in our exile, and raise the horn of his anointed, then every one will say, 'I will lead the Jews and I will gather them'(Benjamin: 80); May God, the Blessed One, have mercy upon us and upon them! (Benjamin: 81 , the closing of the book).

7 Jacob (98) relates how he entered disguised as a Christian; Petahyah (63) tells how he bribed the key-keeper of the cave with a piece of gold; Samuel (105) reports sneaking inside in the middle of the night with the help of locals.

8 Petahyah fell sick during the voyage (Petahyah: 11), and escaped people who were after his money (Peta hyah: 11). Additional 'personal' information revealed regarding Petahyah is aimed to bolster his credibility and serves the pilgrimage, such as the facts that he received a document with the seal of the head of the academy in Babel that ensured his safe conduct and warm welcome in all Jewish communities (Peta hyah: 13), was escorted with armed men on his travels (Peta hyah: 25, 35), tasted the 'manna' (Petahyah: 49), and experienced a personal miracle at Ezekiel's grave (Peta hyah: 27, 29).

9 Joseph b. Isaac, Qivrei Avoth Lines 1-16, see also Prawer 1988: 178.

10 Ten male adults.

11 Translated by Adler mistakenly as belonging to The Emissary (117); see also Prawer 1988: 246. 
12 Jehuda Halevi, Jehuda al-Harizi, Maimonides, Nahmanides and others, all described their emotions at seeing the ruins of the land; see Prawer 1988: 143-165; 176-184, and the reference there.

13 'Halacha' means the complete body of Jewish religious law (includes Biblical laws, Talmudic laws, and laws formed during later times).

${ }^{14}$ Benjamin relates a story told to him by Rabbi Abraham el Constantini, the pious recluse, who was one of the mourners of Jerusalem, who testifies to the tale of the sepulchers of the House of David (Benjamin: 25-26), and Petahyah tells of an old man on his deathbed that swore to him how, on the fast of the day of atonement, he saw a fiery angel and a fiery horse by the well of Sarah, who was offering up his devotion (Petahyah: 67).

${ }^{15}$ Jacob recalled 26 places he has visited in Israel, Benjamin 18, Petahyah 11, Samuel 25, The Emissary 29, and the Disciple 52.

${ }^{16}$ Although changes have been ascribed to forgetfulness, confusion, misapprehension by redactors, the combining of two different voyages into one and so on, still it is hard to accept them. For example, regarding Peta hyah, Prawer writes: [---] an enumeration of the places in the order mentioned by Peta hyah of Regensburg makes it entirely clear that nobody could ever have written an itinerary in that order, let alone tried to travel following these geographical indications (Prawer 1988: 214). Regarding the rest, see Prawer 1988: 184, 188, 196-198, 200, 219-220, 227.

17 The 'regional lists' were imbedded into the itineraries in different levels of redaction: In some of the works the regional lists were edited and developed by the writers with further information (e.g., Petahyah and Jacob); in others they were inserted almost with no change into the text and thus formulate a part of it (Benjamin) or, they virtually are the text, with barely any changes at all (The Emissary). On 'regional lists' and their placement in Hebrew itineraries, see: Reiner 2003: 308-345.

${ }^{18}$ In the itinerary of Jacob, Ya'ari \& Neumark 1946: 62 in the Hebrew edition. This paragraph is missing from Adler's translation.

${ }^{19}$ For more on identification of tombs and sacred space, see Eliade 1957; 1990; Markus 1994; Limor 1988.

${ }^{20}$ In Rachel's grave in Bethlehem (Benjamin: 25). Often the ossuaries had the names of the dead persons scratched on them, which caused false identifications by pilgrims (Wilkinson 1977: 38).

${ }^{21}$ In the Tomb of the Patriarchs in Hebron (Benjamin: 25-26), and see Prawer 1988: 131.

${ }^{22}$ Mainly Benjamin and Petahyah elaborated on traditions, clothes, food, women, horses, dwelling, regimes, ways of learning, praying, fighting, guarding, trading, fishing, shipping, and entertaining, regarding Jewish and especially non-Jewish communities outside the land of Israel.

${ }^{23}$ Commemorating people in literature as a way of panegyric is well known in poetpatron relationship, and see, for example, Yahalom, \& Blau 2002 for the way it was done by al-Harizi in his travels. 


\section{REFERENCE}

Adler, Elkan Nathan 1930. Jewish Travellers. The Broadways travelers. London: Routledge \& Sons.

Adler, Marcus Nathan 1907. The Itinerary of Benjamin of Tudela. London: H. Frowde \& Oxford University Press (available also in: http://www.teachittome.com/seforim2/ seforim/masaos_binyomin_mitudela_with_english.pdf - 14.06.2007).

Baron, Salo Wittmayer 1952. A Social and Religious History of the Jews. New York: Columbia University Press.

Benisch, Abraham (trans.) 1856. Travels of Rabbi Petachia of Ratisbon who in the Latter End of the Twelfth Century Visited Poland, Russia, Little Tartary, the Crimea, Armenia, Assyria, Syria, The Holy Land, and Greece. London: Trubner (available also in: http://www.teachittome.com/seforim2/seforim/travels_of_rabbi_pesachia_of_ regensburg.pdf - 14.06.2007).

Campbell, Mary B. 1988. The Witness and the Other World: Exotic European Travel Writing 400-1600. Ithaca \& London: Cornell University Press.

Dubnov, Semen M. 1968. History of the Jews, Vol. 2: From the Roman Empire to the Early Medieval Period. South Brunswick et al.: Yoseloff.

Eliade, Mircea 1957. Das Heilige und das Profane:Vom Wesen des Religiösen. Rowohlts deutsche Enzyklopädie, 31. Hamburg: Rowohlt.

Ette, Ottmar 2003. Literature on the Move. Internationale Forschungen zur allgemeinen und vergleichenden Literaturwissenschaft, 68. Amsterdam \& New York: Rodopi.

Friedman, Mark 1996. Jewish Pilgrimage after the Destruction of the Second Temple. Rosovsky, Nitza (ed.). City of the Great King: Jerusalem from David to the Present. Cambridge (Massachusetts) \& London: Harvard University Press.

Goitein (= Goyôayn), Šelomo D. 1967-1993. A Mediterranean Society: The Jewish Communities of the Arab World as Portrayed in the Documents of the Cairo Geniza, Vol. I-V. Berkeley: University of California Press.

Hasan-Rokem, Galit 1999. "Homo Viator et Narrans Judaicus": Medieval Jewish Voices in the European Narrative of the Wandering Jew. In: Schneider, Ingo (ed.). Europäische Ethnologie und Folklore im internationalen Kontext: Festschrift für Leander Petzoldt zum 65. Geburtzdag. Frankfurt am Main, pp. 93-102.

Howard, Donald Roy 1980. Writers and Pilgrims: Medieval Pilgrimage Narratives and their Posterity. Berkeley: University of California Press.

Jakimovska-Tošić, Maja 2003. The Literary-Historical Composition in Macedonian Medieval Literature. Blesok 30, January-February (http://www.blesok.com.mk/ tekst.asp?lang=eng\&tekst $=493-14.06 .2007)$.

Kollek, Teddy \& Pearlman, Moshe 1970. Pilgrims to the Holy Land: The Story of Pilgrimage through the Ages. London et al.: Weidenfeld and Nicolson.

Le Beau, Bryan F. \& Mor, Menachem (eds.) 1995. Pilgrims and Travelers to the Holy Land. Studies in Jewish civilization, 7. Omaha (Nebraska): Creighton University Press.

Levanon, Yosef 1980. The Jewish Travellers in the Twelfth Century. Lanham (Maryland): University Press of America. 
Limor, Ora 1988. King David's Tomb on Mt. Zion: The Origins of a Tradition. Jacoby, David \& Tsafrir, Yoram (eds.). Jews, Samaritans and Christians in Byzantine Palestine. Jerusalem: Yad Ben Zvi, pp. 11-23 (Hebrew).

MacCormack, Sabine 1990. Loca Sancta: The Organization of Sacred Topography in Late Antiquity. Ousterhout, Robert (ed.). The Blessings of Pilgrimage. Illinois Byzantine studies, 1. Urbana \& Chicago: University of Illinois Press, pp. 7-40.

Markus, Robert A. 1994. How on Earth Could Places Become Holy? Origins of the Christian Idea of Holy Places. Journal of Early Christian Studies, Vol 2, No 3, pp. 257271.

Prawer, Joshua 1988. The History of the Jews in the Latin Kingdom of Jerusalem. Oxford: Clarendon Press \& New York: Oxford University Press.

Reiner, Elchanan 1988. 'Aliyah va-'aliyah le-regel le-Erets Yisrael: 1099-1517 [Pilgrims and Pilgrimage to Eretz Yisrael: 1099-1517]. Jerusalem: Hebrew University Press.

Reiner, Elchanan 2003. 'Oral versus Written': The Shaping of Traditions of Holy Places in the Middle Ages. Ben-Arieh, Yehoshua \& Reiner, Elchanan (eds.). Ve-zot liYehudah:Mehkarim be-toldot Erets-Yiśra'el ye-yishuvah:Mugashim li-Yehudah Ben Porat = Studies in the History of Eretz Israel: Presented to Yehuda Ben Porat. Jerusalem: Yad Ben Zvi, pp. 308-345 (Hebrew).

Sumption, Jonathan 1975. Pilgrimage: An Image of Mediaeval Religion. London: Faber \& Faber.

Weber, Elka 2004. Sharing the Sites: Medieval Jewish Travellers to the Land of Israel. Allen, Rosamund (ed.). Eastward Bound: Travel and Travellers, 1050-1550. Manchester \& New York: Manchester University Press, pp. 35-53.

Wilken, Robert L. 1996. Christian Pilgrimage to the Holy Land. Rosovsky, Nitza (ed.). City of the Great King: Jerusalem from David to the Present. Cambridge (Massachusetts) \& London: Harvard University Press, pp. 117-135.

Wilkinson, John (trans.) 1977. Jerusalem Pilgrims before the Crusades. Warminster: Aris \& Phillips.

Wilkinson, John (trans.) 1999. Egeria's Travels. Warminster, England: Aris \& Phillips.

Wilkinson, John \& Hill, Joyce \& Ryan, William F. (eds.) 1988. Jerusalem Pilgrimage, 1099-1185. Works issued by the Hakluyt Society, 2nd ser., no. 167. London: Hakluyt Society.

Ya'ari, Avraham (ed.) 1950. Igrot Eretz Yisrael. Tel-Aviv: Massada (Hebrew).

Ya'ari, Avraham (ed.) \& Neumark, Ephraim 1946. Masa'be-erets ha-kedem: Suryah, Kurdistan Aram Naharayim Paras ye-Asyah ha-merkazit. Sifriyat Leṿi ha-Levi, sefer 2. Jerusalem: ha-Ahim Levin-Epshtayn (Hebrew).

Yahalom, Yosef \& Blau, Yehoshua 2002. Mas'e Yehudah: Hamishah pirke masa mehorazim le-Alharizi = The Wanderings of Judah Alharizi: Five Accounts of his Travels. Jerusalem: Yad Ben Zvi (Hebrew).

Yassif, Eli 1999. Legend and History: Historians Read Hebrew Legends of the Middle Ages. Zion, Vol 64, No. 2, pp. 187-219 (Hebrew). 